3. Louveau A, Plog BA, Antila S, Alitalo K, Nedergaard M, Kipnis J. Understanding the functions and relationships of the glymphatic system and meningeal lymphatics. J Clin Invest. 2017;127:3210-3219.

Mony J. de Leon*

Yi Li

Henry Rusinek

*NYU School of Medicine

145 E. 32 St., 5th Floor

New York, NY 10016

E-mail: mony.deleon@nyumc.org

Published online Feb. 9, 2018

DOI: 10.2967/jnumed.117.207068

\section{Research, Research, Otherwise We Are lost!}

"Tanzt, Tanzt sonst sind wir verloren (Dance, Dance otherwise we are lost)." Those words belong to Philippine (Pina) Bausch, who is a German performer of modern dance. The documentary Pina shows the creative way of her choreographies called "Dance Theater" and how they turn into a masterpiece. Pina Bausch took the lead to a new way of exploring, getting beyond the limits and searching for knowledge in her performances. Thus, her vision and different approach have also affected all, but especially young dancers, positively on their performance and creativity (1).

Nuclear medicine has been developing and changing the perspective, especially over the last decades. Recently developed radioisotopes are more used in hybrid imaging technologies; moreover, clinical trials with the new radioligand therapies show favorable outcomes. Once the unclear medicine, nuclear medicine has now become one of the most favorable techniques in imaging (2) and therapy.

In the meantime, with all the developments, combining the specialties with radiology and finding a standart educational pathway have been a discussion among the societies. A survey conducted by the European Association of Nuclear Medicine among young nuclear medicine employees showed clearly that educational improvement is a predominant request. The young scientists emphasized that they needed more education in PET and radionuclide therapy. Apart from education, the survey questioned that the research-based support to young scientists and results were not higher than $40 \%$ of all the attendees (3).

The European Association of Nuclear Medicine and European School of Multimodality Imaging \& Therapy are working hard with group members on providing support to the educational system, with courses, grants, and online educational materials (4). Additionally, the American Board of Nuclear Medicine has recently published an article about nuclear medicine training and recommendations for the education system. They emphasized endorsing dual certification and multispecialty training, which could provide multiple options to residents (5).

All the debates are done to improve the educational system. However, we should also realize once more that education is always effective when it is supported by research.

New ages are full of new ideas. In addition to a standart education, members of our society should be encouraged and promoted to create and develop ideas for research projects. Combining the creativity and the technology is our solution. The unique way of research in nuclear medicine should be underscored and announced to all societies. Fellowship opportunities, congress scholarships, and connections with other researchers could be motivators. If we do not want to get lost in time, we should think inspirationally, create more platforms for new ideas, and support especially the young members of our society on research.

\section{ACKNOWLEDGMENT}

I thank Prof. Rodney Hicks, who is a great mentor, for his kind interest and invaluable support.

\section{REFERENCES}

1. Wenders W. Pina. Berlin, Germany: Neue Road Movies; 2011.

2. Patel CN, Chowdhury FU, Scarsbrook AF. Hybrid SPECT/CT: the end of "unclear" medicine. Postgrad Med J. 2009;85:606-613.

3. Ekmekcioglu O, Zerizer I, Pilkington P, Dias AH, Ristevska N, Jamar F. The young EANM Committee Survey. Eur J Nucl Med Mol Imaging. 2016;43:601603 .

4. Education: The European School of Multimodality Imaging \& Therapy (ESMIT). European Association of Nuclear Medicine website. http://www.eanm.org/esmit/. Accessed February 28, 2018.

5. Segall GM, Grady EE, Fair JR, Ghesani MV, Gordon L. Nuclear medicine training in the United States. J Nucl Med. 2017;58:1733-1734.

Ozgul Ekmekcioglu

Sisli Education and Research Hospital Halaskargazi Cad. Etfal Sk., 34371 Sisli Istanbul, Turkey

E-mail: ozgulek@gmail.com

Published online Jan. 11, 2018. DOI: 10.2967/jnumed.117.206383 